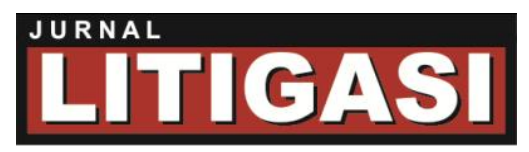

Available online at: http://ejournal.unpas.ac.id/index.php/litigasi

Litigasi, Vol. 16(1), 2015, 2610-2657

DOI: http://dx.doi.org/10.23969/litigasi.v16i1.50

\title{
PEMAHAMAN MASYARAKAT TERHADAP BAHAYA PENYALAH- GUNAAN PEMAKAIAN KEMASAN PRODUK MAKANAN DAN PENEGAKAN HUKUMNYA
}

\section{Dewi Sulistianingsih}

Dosen Fakultas Hukum Universitas Negeri Semarang, Gedung K Kampus Sekaran Gunungpati Semarang, Telp: 024-8507891, Hp: 081392124148 ,E-mail: dewi_sulistia_ningsih@yahoo.co.id

\begin{abstract}
ABSTRAK
Kemasan pangan adalah bahan yang digunakan untuk mewadahi dan atau pembungkus pangan baik yang bersentuhan langsung dengan pangan maupun tidak. Produsen membutuhkan pengetahuan bahan kemasan yang dapat melindungi produk yang dihasilkan, membuat produk lebih menarik, ekonomis, dan aman. Konsumen perlu mengetahui bahan kemasan yang mampu mempertahankan mutu produk, dan aman. Penelitian ini menggunakan pendekatan socio legal atau yuridis sosiologis. Jenis data yang digunakan meliputi data primer yang diperoleh melalui wawancara dan observasi dan data sekunder yang diperoleh melalui studi dokumen. Data dan informasi yang diperoleh, akan di analisis secara kualitatif. Adapun teknik pengecekan keabsahan data digunakan teknik trianggulasi data. Artikel ini membahas mengenai akan arti penting kemasan yang baik untuk makanan. Pemahaman tersebut berkaitan dengan bahaya penyalahgunaan pemakaian kemasan produk makanan. Masyarakat dapat menjadi korban atas kurangnya pengetahuan maupun pemahaman akan penggunaan kemasan yang baik untuk makanan. Kemasan yang tidak baik akan berakibat buruk tidak hanya bagi kesehatan tapi juga bagi lingkungan. Penegakan hukum terhadap penyalahgunaan kemasan juga dilaksanakan belum optimal, hal ini dapat dilihat tingkat pengaduan terhadap penyalahgunaan kemasan masih minim.
\end{abstract}

Kata Kunci: Masyarakat, Makanan, Penegakan, Penyalahgunaan Kemasan.

Copyright @ 2015 , LITIGASI, p-ISSN: 0853-7100; e-ISSN: 2442-2274 
Available online at: http://ejournal.unpas.ac.id/index.php/litigasi

Litigasi, Vol. 16(1), 2015, 2610-2657

DOI: http://dx.doi.org/10.23969/litigasi.v16i1.50

\begin{abstract}
Food packaging is the material used to wrap food either in direct contact with food or not. The knowledge of materials packaging are very important for producers and consumers. Consumers need to know the packaging material that is able to maintain product quality, and safety. This research used socio-legal research. The data type covered primary data obtained through interviews and observation and secondary data obtained through the study of documents. The data and information obtained will be analyzed qualitatively. The technique of checking the validity of the data will be used data triangulation technique. This article discusses about the importance of good packaging for food. The understanding of the dangers associated with the misuse of food product packaging. Communities can become victims of the lack of knowledge and understanding of the use of good packaging for food. Bad packaging is not only bad for health but also for the environment. The implemented of law enforcement against abuse of packaging is not optimal, it can be seen the level of complaints against misuse of packaging is still minimal.
\end{abstract}

Keywords: Community, Food, Enforcement, Packaging Abuse.

Copyright @ 2015, LITIGASI, p-ISSN: 0853-7100; e-ISSN: 2442-2274 
Available online at: http://ejournal.unpas.ac.id/index.php/litigasi

Litigasi, Vol. 16(1), 2015, 2610-2657

DOI: http://dx.doi.org/10.23969/litigasi.v16i1.50

\section{PENDAHULUAN}

Kehidupan dalam bermasyarakat akan selalu bergerak dalam ranah

berbagai kepentingan-kepentingan yang berjalan sesuai dengan kebutuhan masing-masing. Kepentingan tiap manusia berbeda-beda dan kepentingankepentingan tersebut adakalanya berbeda-beda. Mengingat akan banyaknya kepentingan-kepentingan yang beragam tersebut, tidak mustahil terjadi konflik atau bentrokan sesama manusia dalam masyarakat. Konflik tersebut terjadi karena adanya kepentingan yang berbeda dan saling bertentangan.

Tugas hukum adalah untuk menentukan kepentingan manakah yang harus diakui dan dijamin dalam batas-batas dengan suatu minimum persengketaan dan pemborosan (berdasarkan pada insting individu), sebagai akibat insting hidup berkelompok dengan tendens-tendensnya, kesetiaan dan hasrat keberatan. Aristoteles melihat pada manusia itu sebagai makhluk masyarakat. Mengenai ketertiban hukum, disini hukum memelihara, mengembangkan dan mempersembahkan peradaban yang memungkinkan manusia menambah penguasaannya atas alam di luarnya dan mengendalikannya untuk kemanfaatan manusia sehingga bisa mewariskan kekayaan bumi, memelihara dan menambah warisannya itu. Keadilan bisa dirasakan bila orang-orang yang terlibat merasakan bahwa penguasa tidak berpihak. Keadilan adalah lambang dari penyelesaian sosial dari keinginan-keinginan dan tuntutan-tuntutan individual yang bertentangan (Tobing, 1983).

Copyright @ 2015 , LITIGASI, p-ISSN: 0853-7100; e-ISSN: 2442-2274 
Available online at: http://ejournal.unpas.ac.id/index.php/litigasi

Litigasi, Vol. 16(1), 2015, 2610-2657

DOI: http://dx.doi.org/10.23969/litigasi.v16i1.50

Kehidupan masyarakat yang semakin komplek dan dengan semakin berkembangnya teknologi diberbagai bidang, dimana hasil produk begitu melimpah, faktor keselamatan bagi para konsumen dalam menikmati hasil produk perlu diperhatikan seperti produk makanan. Bagi pemerintah, pangan yang beredar harus aman, bermutu dan bergizi karena pangan sangat dibutuhkan bagi pertumbuhan, pemeliharaan dan peningkatan derajat kesehatan serta kecerdasan masyarakat perlu dilindungi dari pangan yang merugikan dan/atau membahayakan keselamatan. Pangan yang baik sekalipun tidak menjamin kesehatan bagi masyarakat manakala kemasan dari pangan tersebut membahayakan masyarakat tersebut. Kemasan merupakan hal yang sepele bagi sebagian masyarakat namun kemasan merupakan hal penting karena kemasan melindungi produk terhadap berbagai kemungkinan yang dapat menjadi sebab timbulnya kerusakan produk.

Pengemasan menjadi hal yang sangat penting karena akan memudahkan dalam kegiatan transportasi dan penyimpanan. Pengertian transportasi tidak selalu memindahkan barang dari satu tempat ke tempat lain. Akan tetapi bisa juga diartikan memindahkan bahan pangan dari piring ke dalam mulut kita. Sebagai contoh : memindahkan nasi dari piring ke mulut menggunakan sendok, maka sendok berperan sebagai bahan pengemas.

Teknologi pengemasan dan pemilihan jenis bahan pengemas dirancang sedemikian rupa sehingga bahan pangan dapat terhindar dari serangan serangga maupun mikroba. Di samping itu juga dapat menghasilkan produk yang memiliki

Copyright @ 9 2015, LITIGASI, p-ISSN: 0853-7100; e-ISSN: 2442-2274 
daya simpan yang relatif lama tetapi juga memiliki nilai nutrisi yang relatif masih baik pula, meningkatkan nilai tambahan yang dikemas seperti bahan atau produk lebih menarik, dan harga jual lebih tinggi.

Manusia di dalam masyarakat memerlukan perlindungan dalam berbagai kepentingan. Perlindungan kepentingan tersebut dapat tercapai dengan terciptanya pedoman atau peraturan hidup yang menentukan bagaimana manusia harus bertingkah laku dalam masyarakat agar tidak merugikan orang lain dan dirinya sendiri. Demi keselamatan dan keamanan bagi konsumen para produsen dituntut untuk betul-betul memperhatikan mutu kemasan yang dapat memberi perlindungan juga sebagai bagian dari tanggung jawab produsen. Sebenarnya berbagai jenis dan bentuk kemasan memudahkan makanan dan minuman didistribusikan karena lebih awet, higienis jika dikemas dengan baik. Konsumen merasa nyaman dengan tersedianya produk pangan terkemas berbagai bentuk dan ukuran, disatu sisi kemasan memberikan keuntungan dan disisi lain kemasan juga perlu diwaspadai karena tidak semua bahan pengemas aman terhadap makanan dan minuman sehingga harus memenuhi syarat kemasan. Oleh karena itu Undang - Undang No 7 tahun 1996 tentang pangan pada bagian keempat memberikan pengaturan mengenai kemasan pangan yang harus diperhatikan bagi semua produsen dalam memproduksi makanan dan minuman sebagai bentuk tanggung jawabnya.

Copyright @ 9 2015, LITIGASI, p-ISSN: 0853-7100; e-ISSN: 2442-2274 
Available online at: http://ejournal.unpas.ac.id/index.php/litigasi

Litigasi, Vol. 16(1), 2015, 2610-2657

DOI: http://dx.doi.org/10.23969/litigasi.v16i1.50

Perundang-undangan disusun dengan terarah pada pengkaidahan kejadiankejadian tertentu dengan jalan menimbang-nimbang kepentingan-kepentingan yang bermain didalamnya yang satu terhadap yang lainnya. Jika kita sudah mau berbicara tentang apa yang mau dicapai atau yang mau dimaksud oleh pembentuk undang-undang dengan aturan tersebut, maka kita akan sampai paling dekat ke situ dengan jalan menelusuri kejadian-kejadian apa yang paling jelas (eviden) termasuk ke dalam wilayah jangkauan dari ketentuan yang bersangkutan. Hukum sebagai kumpulan peraturan atau kaedah mempunyai isi yang bersifat umum dan normatif, umum karena berlaku bagi setiap orang dan normatif karena menentukan apa yang seyogyanya dilakukan, apa yang tidak boleh dilakukan atau harus dilakukan serta menentukan bagaimana caranya melaksanakan kepatuhan pada kaedah-kaedah (Sudikno Mertokusumo, 2003). Hukum sebagai suatu peraturan yang logis dan konsisten apabila dalam suatu peraturan perundang-undangan yang dibuat itu secara efektif dan didukung oleh sarana-sarana yang menandai. Agar unsur-unsur dalam hukum itu dapat terpenuhi dan dapat digunakan secara efektif sebagai suatu perantara, maka tidak hanya memahami hukum pada bentuk-bentuk yang sudah jadi, melainkan kita juga memahami latar belakang yang mendasari pemberlakuan suatu peraturan. Berkaitan dengan hukum sebagai suatu kumpulan peraturan, ada berbagai regulasi yang mengenai kemasan makanan, dalam praktek belum dipatuhi oleh para produsen atau pelaku usaha di masyarakat sehingga hal tersebut sangat merugikan konsumen.

Copyright @ 9 2015, LITIGASI, p-ISSN: 0853-7100; e-ISSN: 2442-2274 
Available online at: http://ejournal.unpas.ac.id/index.php/litigasi

Litigasi, Vol. 16(1), 2015, 2610-2657

DOI: http://dx.doi.org/10.23969/litigasi.v16i1.50

Hukum memiliki fungsi dalam kehidupan masyarakat sebagai sarana untuk melayani hubungan sesama anggota masyarakat sehingga diharapkan tercipta harmonisasi. Fungsi hukum dalam hal ini tidak hanya bertujuan untuk menertibkan dan mengatur pergaulan manusia dalam masyarakat saja atau hanya menyelesaikan masalah-masalah yang timbul ( $R$, Soeroso, 2004). Hukum dapat juga berfungsi untuk menciptakan hubungan yang harmonis dalam masyarakat.

Hukum diharapkan tidak lagi mengikuti masyarakat, melainkan harus dapat memberi arah kepada masyarakat, oleh karena itu perlu diperhatikan 2 macam fungsi hukum yang berdampingan satu sama lain (Satjipto Rahardjo, 1997) :

1. Fungsi hukum sebagai sarana pengendalian sosial; dan

2. Sebagai sarana untuk melakukan social enginering.

Pertama, yang mengkonsepkan hukum sebagai sarana pengendalian sosial. Fungsi hukum sebagai alat pengendalian sosial dapat diterangkan sebagai fungsi hukum untuk menetapkan tingkah laku mana yang dianggap penyimpangan terhadap aturan hukum, dan apa sanksi atau tindakan yang dilakukan oleh hukum jika terjadi penyimpangan tersebut. Kedua, yang mengkonsepkan hukum sebagai sarana rekayasa sosial (social enginering). Dalam hal ini fungsi hukum sebagai alat untuk mengubah masyarakat. Hukum dapat menciptakan perubahan sosial dalam masyarakat atau setidak-tidaknya dapat memacu perubahan-perubahan yang berlangsung dalam masyarakat.

Copyright @ 9 2015, LITIGASI, p-ISSN: 0853-7100; e-ISSN: 2442-2274 
Available online at: http://ejournal.unpas.ac.id/index.php/litigasi

Litigasi, Vol. 16(1), 2015, 2610-2657

DOI: http://dx.doi.org/10.23969/litigasi.v16i1.50

Berdasarkan 2 macam fungsi hukum tersebut di atas, maka bekerjanya hukum dalam masyarakat tidak lepas dari kepentingan negara demi kesejahteraan warganya dan dalam pelaksanaannya didelegasikan pada unsur aparatur pemerintah khususnya yang bergerak dalam bidang penegakan hukum seperti kepolisian, kejaksaan dan pengadilan.

Dunia usaha merupakan suatu dunia yang boleh dikatakan tidak dapat berdiri sendiri. Banyak aspek dari berbagai macam dunia lainnya turut terlibat baik langsung maupun tidak langsung dengan dunia usaha ini. Keterkaitan tersebut kadangkala tidak memberikan prioritas atas dunia usaha, yang pada akhirnya membuat dunia usaha harus tunduk dan mengikuti rambu-rambu yang ada dan seringkali bahkan mengutamakan dunia usaha sehingga mengabaikan aturan-aturan yang telah ada.

Negara memang tidak dapat berjalan dan maju tanpa adanya dunia usaha yang berkembang secara pesat dan efisien. Namun efisiensi bukanlah suatu perkataan yang sederhana dan muluk. Banyak makna terkandung di dalamnya. Makna-makna tersebut tidak lain adalah penjabaran dari berbagai macam ramburambu, baik yang terbentuk sebagai suatu aturan main perundang-undangan maupun hanya dalam bentuk-bentuk "kode etik".

Pesatnya perkembangan dunia usaha adakalanya tidak diimbangi dengan "penciptaan" rambu-rambu pengawas. Dunia usaha yang berkembang terlalu pesat sehingga meninggalkan rambu-rambu yang ada jelas tidak akan menguntungkan

Copyright $\odot$ 2015, LITIGASI, p-ISSN: 0853-7100; e-ISSN: 2442-2274 
pada akhirnya (Ahmad Yani \& Gunawan Widjaja, 2002). Produsen atau pelaku usaha bersaing ketat untuk meraih konsumen dengan menciptakan berbagai inovasi desain kemasannya dengan berbagai macam kemasan seperti kertas, plastik, kaleng, alumunium, gelas, styrofoam dan lain-lain. Guna menjaga kualitas dan keamanan produk yang dikemasnya produsen atau pelaku usaha membutuhkan kemasan produknya yang dapat memenuhi standar keamaman pangan.

Contoh dari kasus penggunaan kemasan makanan yang tidak baik yaitu dengan riset yang membuktikan bahwa styrofoam diragukan keamanannya. Pada tahun 2000, di US terdapat produksi styrofoam hingga 3 juta per tahunnya. Dari limbah yang dihasilkan, hanya $1 \%$ yang mengalami recycle sementara 2,3 juta limbahnya ditimbun dalam tanah (Ward et al., 2006). Pada Juli 2001, Divisi Keamanan Pangan Pemerintah Jepang mengungkapkan bahwa residu styrofoam dalam makanan sangat berbahaya. Residu itu dapat menyebabkan endocrine disrupter chemicals (EDC), yaitu suatu penyakit yang terjadi akibat adanya gangguan pada sistem endokrinologi dan reproduksi manusia akibat bahan kimia karsinogen dalam makanan styrofoam yang ringan dan praktis ini (Winarno, tanpa tahun).

Hasil survei yang dilakukan di AS pada tahun 1986, ditemukan 100 persen jaringan lemak orang Amerika mengandung styrene yang berasal dari styrofoam. Bahkan pada penelitian 2 tahun berikutnya, kandungan styrene sudah mencapai ambang batas yang bisa memunculkan gejala gangguan saraf. Sebuah studi di New

Copyright $\odot$ 2015, LITIGASI, p-ISSN: 0853-7100; e-ISSN: 2442-2274 
Available online at: http://ejournal.unpas.ac.id/index.php/litigasi

Litigasi, Vol. 16(1), 2015, 2610-2657

DOI: http://dx.doi.org/10.23969/litigasi.v16i1.50

Jersey, AS, menemukan bahwa 75 persen ASI mengalami kontaminasi styrene yang berasal dari konsumsi ibu yang menggunakan wadah styrofoam, dalam jangka panjang dapat mengakibatkan penumpukan styrene dalam tubuh, dan menimbulkan gejala - gejala sistem saraf seperti kelelahan, gelisah, sulit tidur. Bahkan styrofoam dapat menyebabkan kemandulan atau menurunkan kesuburan. Anak yang terbiasa mengonsumsi styrene bisa kehilangan kreativitas dan pasif (Anies, Suara Merdeka, 2009).

Penggunaan bahan styrofoam sebagai wadah makanan memiliki dampak baik secara langsung maupun tidak langsung terhadap kesehatan, namun masih menjadi pertanyaan mengapa masyarakat tetap menggunakan bahan styrofoam tersebut sebagai wadah atau kemasan makanan. Fenomena tersebut seyogyanya harus ada penanggulangan terhadap penggunaan bahan styrofoam sebagai wadah makanan yang baik melalui berbagai regulasi maupun pemahaman masyarakat akan arti penting kesehatan bagi dirinya sendiri.

Berdasarkan uraian di atas maka permasalahan yang akan diangkat dalam penelitian ini adalah sebagai berikut : 1) Bagaimana tingkat pemahaman masyarakat terhadap bahaya penyalahgunaan pemakaian kemasan produk makanan, 2) Bagaimana penegakan hukum terhadap pelanggaran penyalahgunaan pemakaian kemasan pada produk makanan.

Copyright $\odot$ 2015, LITIGASI, p-ISSN: 0853-7100; e-ISSN: 2442-2274 
Available online at: http://ejournal.unpas.ac.id/index.php/litigasi

Litigasi, Vol. 16(1), 2015, 2610-2657

DOI: http://dx.doi.org/10.23969/litigasi.v16i1.50

\section{METODE PENELITIAN}

Metode pendekatan dalam penelitian ini adalah bersifat socio legal atau yuridis sosiologis. Pendekatan yuridis dilakukan untuk menganalisis regulasi yang mengatur mengenai kemasan produk makanan dan penegakan hukumnya dalam penyalahgunaan pemakaian kemasan makanan. Pendekatan sosiologis dimaksudkan untuk menganalisis perilaku masyarakat atau analisis realita sosial masyarakat akan pemahaman arti penting kemasan makanan.

Penelitian selalu memerlukan bahan atau data yang akan dicari kemudian diolah dan selanjutnya dianalisis untuk mencari jawaban dari permasalahan penelitian yang diajukan. Soerjono Soekanto menggunakan istilah data sekunder atau data kepustakaan yang di dalamnya mengandung bahan hukum, sedangkan Peter Mahmud tidak menggunakan istilah data tetapi bahan hukum, alasan pembedaan bahan dengan data yaitu (Mukti Fajar dan Yulianto Achmad, 2010) :

1. Istilah bahan adalah terjemahan dari bahasa Inggris yang disebut material. Sementara data lebih bersifat informasi. Dalam penelitian normatif, sistem hukum dianggap telah mempunyai seluruh material atau bahan, sehingga tidak perlu dicari jalan keluar dari sistem norma tersebut. Data adalah informasi yang harus dicari ke "luar" dari sistem.

Copyright $\odot$ 2015, LITIGASI, p-ISSN: 0853-7100; e-ISSN: 2442-2274 
Available online at: http://ejournal.unpas.ac.id/index.php/litigasi

Litigasi, Vol. 16(1), 2015, 2610-2657

DOI: http://dx.doi.org/10.23969/litigasi.v16i1.50

2. Bahan digunakan untuk istilah bagi sesuatu yang normatif dokumentatif, bahan penelitian hukum dicari dengan cara penelitian kepustakaan (termasuk wawancara dengan nara sumber), sementara data digunakan untuk sesuatu yang informatif empiris dalam penelitian yuridis empiris yang harus dicari melalui pengamatan atau observasi ke dunia nyata.

Penelitian ini memerlukan bahan-bahan sebagai sumber penelitian yang akan dicari untuk diolah dan selanjutnya akan dianalisis guna mencari jawaban dari permasalahan penelitian yang penulis ajukan. Bahan-bahan tersebut yaitu : (1) Bahan hukum primer yakni bahan hukum yang terdiri dari aturan hukum yang diurut berdasarkan hierarki mulai dari UUD 1945, TAP-MPR, Undangundang, Peraturan Pemerintah, dan aturan lain di bawah undang-undang, serta bahan hukum asing sebagai pembanding bahan hukum yang dianalisis untuk mengetahui pemahaman masyarakat terhadap bahaya penyalahgunaan pemakaian kemasan produk dan penegakan hukumnya; (2) Bahan hukum sekunder adalah badan hukum yang diperoleh dari buku teks, jurnal-jurnal asing, pendapat para sarjana, kasus-kasus hukum, serta simposium yang dilakukan para pakar terkait dengan pembahasan tentang mengetahui pemahaman masyarakat terhadap bahaya penyalahgunaan pemakaian kemasan produk dan penegakan hukumnya. Bahan hukum sekunder yang digunakan merupakan bahan-bahan hukum yang erat hubungannya dengan bahan hukum primer dan dapat membantu menganalisis serta memahami bahan-bahan hukum primer; (3) Bahan hukum 
Available online at: http://ejournal.unpas.ac.id/index.php/litigasi

Litigasi, Vol. 16(1), 2015, 2610-2657

DOI: http://dx.doi.org/10.23969/litigasi.v16i1.50

tersier adalah bahan hukum yang memberikan petunjuk atau penjelasan bermakna terhadap bahan hukum primer dan sekunder, seperti kamus hukum, ensiklopedia, dan lain-lain. Bahan hukum tersier dalam penelitian ini digunakan kamus hukum untuk mempertegas peristilahan dalam artikel ini, seperti istilah penegakan hukum, sanksi hukum, kesadaran hukum, dan sebagainya. Ensiklopedi digunakan untuk memperjelas istilah-istilah dibidang kesehatan seperti, styrofoam, endocrine disrupter chemicals (EDC), styrene, dan lain-lain.

Teknik pengumpulan yang dipergunakan dalam penelitian ini dilakukan dengan mengumpulkan dan menginventarisir perundang-undangan yang berlaku sebagai bahan hukum primer. Disamping itu juga dilakukan pengumpulan dan inventarisir terhadap bahan hukum sekunder, serta bahan hukum tersier.

Bahan hukum primer, bahan hukum sekunder maupun bahan hukum tersier dikumpulkan berdasarkan topik permasalahan yang telah dirumuskan dan diklasifikasi menurut sumber dan hierarkinya untuk dikaji secara komprehensif.

Teknik pengumpulan bahan hukum yang digunakan menggunakan metode sistematis (sistem kartu), yaitu setelah mendapat semua bahan yang diperlukan kemudian dibuat catatan mengenai hal - hal yang dianggap penting bagi penelitian yang dilakukan (Soerjono Soekanto dan Sri Mamudji, 2004). Sistem kartu yang digunakan dalam penelitian ini adalah kartu kutipan dan kartu bibliografi. Kartu kutipan dipergunakan untuk mencatat atau mengutip sumber bahan hukum yang digunakan yang berisi nama pengarang atau penulis, judul buku, halaman dan mengutip hal-hal yang dianggap penting agar bisa menjawab

Copyright @ C 2015, LITIGASI, p-ISSN: 0853-7100; e-ISSN: 2442-2274 
Available online at: http://ejournal.unpas.ac.id/index.php/litigasi

Litigasi, Vol. 16(1), 2015, 2610-2657

DOI: http://dx.doi.org/10.23969/litigasi.v16i1.50

permasalahan dalam penelitian ini, sedangkan kartu bibliografi dipergunakan untuk mencatat sumber bacaan bagi kepentingan penyusunan daftar pustaka.

Penelitian ini juga mempergunakan wawancara sebagai teknik pengumpulan data. Kegiatan wawancara dilakukan antara peneliti dengan responden sehingga terjadi interaksi antara peneliti dengan para responden yang terdiri dari pemikir dan pakar hukum sesuai dengan kajian yang dianut, melalui pemikiran, pandangan, pendapat, atau pernyataan mereka sebagaimana dapat dibaca di berbagai literatur yang ada.

Pengumpulan informasi dengan wawancara berdasarkan pedoman wawancara yang telah disusun dan narasumber yang telah ditetapkan terlebih dahulu, sesuai dengan data dan informasi yang diharapkan.

Penelitian dilakukan di Kota Semarang dengan dasar pertimbangan bahwa Kota Semarang adalah ibukota Jawa Tengah yang merupakan kota perdagangan Jawa Tengah. Semarang dapat dikatakan sebagai kota yang dapat mewakili kotakota besar lainnya di negara Indonesia walaupun hasil dari penelitian ini pada setiap kota dapat menghasilkan kesimpulan yang berbeda.

Metode yang digunakan dalam penelitian ini adalah metode purposive sampling yaitu pengambilan sample dengan pertimbangan tertentu sesuai dengan kriteria yang telah ditentukan dan selalu mendasarkan diri pada informasi dan pengetahuan yang telah diperoleh atau dicek dengan ciri-ciri khusus suatu populasi (Ronny Hanitijo, 1990). Subyek penelitian ini adalah masyarakat Kota

Copyright $\odot$ 2015, LITIGASI, p-ISSN: 0853-7100; e-ISSN: 2442-2274 
Available online at: http://ejournal.unpas.ac.id/index.php/litigasi

Litigasi, Vol. 16(1), 2015, 2610-2657

DOI: http://dx.doi.org/10.23969/litigasi.v16i1.50

Semarang. Sample yang digunakan adalah 30 produsen dan 30 masyarakat pengguna kemasan makanan minuman.

Data dan informasi yang diperoleh, baik yang diperoleh melalui studi pustaka maupun wawancara, akan di analisis secara kualitatif. Tahap pengolahan dan menganalisis merupakan langkah setelah pengumpulan bahan hukum. Semua bahan hukum yang ada yang telah didapat dari hasil penelitian diperlukan untuk menjawab permasalahan yang ada. Adapun bahan yang diperoleh dalam penelitian studi kepustakaan, aturan perundang-undangan, dan artikel penulis uraikan dan hubungkan sedemikian rupa, sehingga disajikan dalam penulisan yang lebih sistematis guna menjawab permasalahan yang telah dirumuskan.

Data yang didapatkan dari studi dokumen adalah data deskriptif yang berwujud rangkaian kata-kata kemudian direduksi melalui beberapa tahap. Pertama reduksi data, pemusatan perhatian pada penyederhanaan, pengabstrakan dan transformasi data kasar yang didapatkan selama studi dokumen. Seluruh data dikelompokkan berdasarkan sifatnya dan diorganisasikan menjadi simpulan yang lebih luas. Tahap kedua dari rangkaian analisis adalah penyajian data. Dalam langkah ini dilakukan penyusunan sekumpulan informasi menjadi suatu pernyataan yang memungkinkan penarikan simpulan. Maksud dari langkah ini adalah untuk mensistematisasikan dan menyederhanakan informasi yang beragam dalam kesatuan bentuk yang disederhanakan, selektif sehingga lebih mudah untuk dipahami. Tahap ketiga yaitu menarik simpulan berdasarkan reduksi dan

Copyright @ C 2015, LITIGASI, p-ISSN: 0853-7100; e-ISSN: 2442-2274 
Available online at: http://ejournal.unpas.ac.id/index.php/litigasi

Litigasi, Vol. 16(1), 2015, 2610-2657

DOI: http://dx.doi.org/10.23969/litigasi.v16i1.50

penyajian data yang telah dilakukan pada tahap sebelumnya. Pada tahap awal simpulan masih bersifat longgar, kemudian diringkas lagi menjadi lebih rinci.

Analisis bahan dimulai dengan menelaah seluruh data yang didapat dari berbagai sumber, kemudian dilakukan reduksi data dengan cara membuat rangkuman inti (abstraksi) sehingga menjadi satuan informasi. Setelah melewati satuan-satuan kegiatan proses analisis ini kemudian akan disusun sambil membuat coding (pengkodean). Berdasarkan proses ini maka bahan dan data dapat ditafsirkan dan diolah menjadi hasil yang bersifat final. Proses analisis bahan dan data ini bersifat deskriptif, evaluatif dan preskriptif. Dalam upaya mensistematisasi dan memahami data dalam bingkai analisis, data primer maupun sekunder yang telah terkumpul dianalisis dengan menggunakan analisis kuantitatif maupun kualitatif. Analisis kuantitatif diarahkan pada pemaparan gejala secara deskriptif, sedangkan analisis kualitatif dilakukan secara induktif-deduktif, dan diarahkan kepada informasi-informasi responden yang tidak dapat diungkapkan secara kuantitatif, tetapi sangat penting sebagai pendukung upaya mencari jawaban dari permasalahan dari penelitian ini.

Model analisis yang dipakai adalah model interaktif (interactive model of analysis) yakni melalui pola pengumpulan data (Esmi Warrassih, 1999), kemudian reduksi data, display data dan berakhir dengan simpulan (Mattew B, Miles dan A, Michael Huberman, 1992). Apabila simpulan dirasa kurang mantap, maka untuk mengetahui keakuratan dan kehandalan data dilakukan

Copyright @ 2015 , LITIGASI, p-ISSN: 0853-7100; e-ISSN: 2442-2274 
dengan triangulasi atau multi strategi, yaitu suatu metode untuk mengatasi masalah sebagai akibat dari kajian yang hanya mengandalkan satu teori saja, satu macam data dan satu metode penelitian saja (Britha Mikkelsen, 1999). Triangulasi ini meliputi :

1. Triangulasi data, artinya data yang terkumpul dari sumber, tempat dan peran yang berbeda dilakukan pengecekan silang. Triangulasi sumber dilakukan dengan jalan membandingkan data hasil pengamatan dengan hasil wawancara, membandingkan pendapat yang dilakukan secara terbuka dengan yang diungkapkan sendiri secara pribadi, membandingkan pendapat atau perspektif seseorang dengan berbagai pendapat dan pandangan sesuai dengan kualifikasi tertentu serta membandingkan hasil wawancara dengan isi suatu dokumen tertentu.

2. Triangulasi teori, artinya suatu topik penelitian dikaji dari berbagai aspek dan perspektif teoritis. Persoalan yang dikaji dalam penelitian ini dikaji dari dua arah yang dipandang dapat saling menunjang, yakni kajian secara filosofis dengan secara sosiologis;

3. Triangulasi metode, artinya data yang diperoleh merupakan hasil aplikasi dari beberapa metode pengumpulan data untuk memperkuat keabsahan data. Dalam penelitian ini dipadukan dari beberapa metode pengumpulan data, yakni transkripsi atau dokumentasi, wawancara dan observasi (J) Lexy Moleong, 1996).

Copyright @ C 2015, LITIGASI, p-ISSN: 0853-7100; e-ISSN: 2442-2274 
Available online at: http://ejournal.unpas.ac.id/index.php/litigasi

Litigasi, Vol. 16(1), 2015, 2610-2657

DOI: http://dx.doi.org/10.23969/litigasi.v16i1.50

Setelah data dianggap valid kemudian dikonstruksikan untuk mendapatkan pemahaman yang lebih luas tentang permasalahan yang diajukan dalam penelitian ini. Sebelum dikonstruksikan, data yang terkumpul dianalisis secara emic dan etic (David Silverman, 1993). Analisis emic diperlukan untuk mendapatkan pemahaman tentang makna keadilan menurut para pelaku dan korban atau keluarga korban tindak pidana terhadap nyawa dan tubuh. Hasil analisis emic tersebut selanjutnya diinterpretasikan secara etic menurut pemahaman orang lain, baik literatur-literatur pilihan maupun dari para tokoh agama, dan lain sebagainya. Dengan perpaduan analisis secara emic-etic tersebut diharapkan dapat diperoleh hasil penelitian yang tidak hanya berhenti pada tataran deskriptif semata, melainkan sampai pada tingkat eksplanasi (penjelasan) agar dapat dipahami secara lebih luas dan komperhensif.

Triangulasi data dilakukan terhadap produsen dan konsumen sebagai subyek penelitian. Dari data tersebut, kemudian dilakukan triangulasi dengan BPOM.

\section{HASIL PENELITIAN DAN ANALISIS}

Perhelatan Akbar, Pekan Kebudayaan Aceh (PKA) $V$ dan Aceh Internasional Expo 2009 yang dibuka oleh Presiden Susilo Bambang Yudhoyono dan berlangsung sejak tanggal 2 sampai 11 Agustus 2009 mempunyai arti tersendiri bagi Balai Besar POM (BBPOM) di Banda Aceh. Dalam PKA tersebut,

Copyright $\odot$ 2015, LITIGASI, p-ISSN: 0853-7100; e-ISSN: 2442-2274 
Available online at: http://ejournal.unpas.ac.id/index.php/litigasi

Litigasi, Vol. 16(1), 2015, 2610-2657

DOI: http://dx.doi.org/10.23969/litigasi.v16i1.50

stand BBPOM ramai dikunjungi pengunjung yang sangat antusias terhadap materi Penyebaran Informasi tentang Obat dan Makanan antara lain yaitu : (1) Bagaimana mengenali bahaya pangan berformalin dan mengandung boraks; (2) Apa yang harus diperhatikan dalam penggunaan obat; (3) Bagaimana memilih kosmetika yang dibenarkan untuk dipakai; (4) Bagaimana memilih Obat Tradisional yang baik dan mengetahui yang mengandung Bahan Kimia Obat sesuai informasi public warning; (5) Bagaimana memilih wadah kemasan untuk makanan (Warta POM, 2009).

Mengamati acara PKA tersebut, wadah kemasan untuk makanan menjadi satu dari beberapa hal yang merupakan pertanyaan yang diminati oleh masyarakat. Hal ini membuktikan bahwa masyarakat memiliki rasa ingin tahu yang cukup besar untuk sesuatu hal yang berkaitan dengan kemasan makanan.

Sebelum membicarakan arti penting kemasan dalam produk makanan dan minuman terlebih dahulu untuk dapat diketahui apa sebenarnya yang dimaksud dengan kemasan. Undang-Undang RI Nomor 7 tahun 1996 tentang Pangan Bab I ketentuan umum Pasal 1 butir 10 disebutkan kemasan pangan adalah bahan yang digunakan untuk mewadahi dan atau pembungkus pangan baik yang bersentuhan langsung dengan pangan maupun tidak. Menurut peraturan Menteri Kesehatan RI No. 329 / Menkes / Per / XII / 76 tentang Produksi dan peredaran Pangan Pasal I butir 1 wadah adalah barang yang dipakai untuk mewadahi atau membungkus makanan langsung dengan isi. Menurut peraturan

Copyright $\odot$ 2015, LITIGASI, p-ISSN: 0853-7100; e-ISSN: 2442-2274 
Available online at: http://ejournal.unpas.ac.id/index.php/litigasi

Litigasi, Vol. 16(1), 2015, 2610-2657

DOI: http://dx.doi.org/10.23969/litigasi.v16i1.50

Menteri Kesehatan RI No. 329 / Menkes / Per / XII / 76 tentang Produksi dan peredaran Pangan Pasal I butir 2 pembungkus adalah barang yang digunakan untuk membungkus makanan yang tidak berhubungan langsung dengan isi.

Memperhatikan pengertian kemasan pangan seperti di atas bahwa kemasan pangan adalah salah satu bahan yang dapat dipakai atau dipergunakan sebagai pembungkus pangan hal ini minuman dan makanan. Adapun tujuan akhir pemakaian kemasan tidak lain agar makanan atau minuman yang sehat untuk memenuhi syarat makanan yang sehat untuk dikonsumsi, disamping itu juga dapat memenuhi unsur keamanannya. Bila diperhatikan ketentuan tentang kemasan pangan yang ada dalam Pasal 16 UU No. 7 Tahun 1996 tentang Pangan, disitu tersirat arti pentingnya keberadaan kemasan pangan. Pasal 16 ayat (1) menyatakan bahwa setiap orang yang memproduksi pangan untuk diedarkan dilarang menggunakan bahan apapun sebagai kemasan pangan yang dinyatakan terlarang dan atau yang dapat melepaskan cemaran yang merugikan atau membahayakan kesehatan manusia. Pasal 16 ayat (2) menyatakan bahwa pengemasan pangan diedarkan dilakukan melalui tata cara yang dapat menghindarkan terjadinya kerusakan dan pencemaran. Dalam ayat (3) nya dinyatakan lebih lanjut bahwa Pemerintah menetapkan bahan yang dilarang digunakan sebagai kemasan pangan dan tata cara pengemasan pangan tertentu yang diperdagangkan. Pasal 16 ayat (1) jelas mengamanatkan bagi siapa saja yang memproduksi pangan untuk dipasarkan harus memperhatikan kemasan atas

Copyright $\odot$ 2015, LITIGASI, p-ISSN: 0853-7100; e-ISSN: 2442-2274 
Available online at: http://ejournal.unpas.ac.id/index.php/litigasi

Litigasi, Vol. 16(1), 2015, 2610-2657

DOI: http://dx.doi.org/10.23969/litigasi.v16i1.50

produk pangannya. Kemasan atau pembungkus bahan pangan dan minuman jangan sampai menimbulkan pencemaran yang dapat merugikan konsumen dan membahayakan manusia. Begitu juga ketentuan dalam Pasal 16 ayat (2) dengan tegas disebutkan untuk pengemasan makanan dan minuman yang diedarkan harus melalui tata cara yang dapat menghindarkan terjadinya kerusakan atau pencemaran. Oleh karena itu dalam Pasal 16 ayat (3) pemerintah dengan tegas memberikan larangan bagi siapa yang memproduksi makanan dan minuman yang dapat membahayakan kesehatan konsumen dan dapat menimbulkan pencemaran terhadap hasil produk.

1. Pemahaman Masyarakat Terhadap Bahaya Penyalahgunaan Pemakaian Kemasan Produk Makanan

Pengertian kemasan pangan menurut Peraturan Kepala Badan Pengawas Obat dan Makanan Republik Indonesia Nomor : Hk 00.05.55.6497 Tentang Bahan Kemasan Pangan, kemasan pangan adalah bahan yang digunakan untuk mewadahi dan/atau membungkus pangan baik yang bersentuhan langsung dengan pangan maupun tidak. Pengertian umum dari kemasan adalah suatu benda yang digunakan untuk wadah atau tempat dan dapat memberikan perlindungan sesuai dengan tujuannya. Adanya kemasan dapat membantu mencegah atau mengurangi kerusakan, melindungi bahan yang ada di dalamnya dari pencemaran serta gangguan fisik seperti gesekan, benturan dan getaran. Dari segi promosi kemasan berfungsi sebagai perangsang atau daya tarik pembeli.

Copyright @ C 2015, LITIGASI, p-ISSN: 0853-7100; e-ISSN: 2442-2274 
Available online at: http://ejournal.unpas.ac.id/index.php/litigasi

Litigasi, Vol. 16(1), 2015, 2610-2657

DOI: http://dx.doi.org/10.23969/litigasi.v16i1.50

Sebuah kemasan mempunyai fungsi yang paling mendasar secara fisik sebagai sebuah wadah dan pelindung dari produk yang ada di dalamnya. Sebagai sebuah wadah dan pelindung, maka secara fisik, sebuah kemasan harus andal terhadap benturan, tekanan, temperatur, air, debu, dan lain-lain. Tidak hanya andal bagi produk di dalamnya, sebuah kemasan juga harus direncanakan dengan mempertimbangkan penempatan dan penyimpanannya terutama dalam jumlah banyak.

Kemasan makanan dan minuman secara praktik dalam masyarakat digunakan oleh masyarakat baik produsen maupun konsumen dengan berbagai jenis dan bentuk kemasan dengan tujuan untuk memudahkan pendistribusian dan mengawetkan makanan dan minuman dalam kemasan. Kemasan yang beredar di masyarakat bermacam-macam bahan dari yang paling sederhana mulai dari kertas sampai paling modern yaitu polivinil. Dewasa ini secara garis besar bahan kemasan terdapat lima macam yaitu : kertas, gelas, plastik, logam dan kaleng. Pembahasan mengenai kemasan yang tidak baik tersebut yaitu sebagai berikut :

a. Kertas

Beberapa kertas kemasan dan non-kemasan (kertas koran dan majalah) yang sering digunakan untuk membungkus makanan, terdeteksi mengandung timbal $(\mathrm{Pb})$ melebihi batas yang ditentukan. Di dalam tubuh manusia, timbal masuk melalui saluran pernapasan atau pencernaan

Copyright @ $\odot$ 2015, LITIGASI, p-ISSN: 0853-7100; e-ISSN: 2442-2274 
Available online at: http://ejournal.unpas.ac.id/index.php/litigasi

Litigasi, Vol. 16(1), 2015, 2610-2657

DOI: http://dx.doi.org/10.23969/litigasi.v16i1.50

menuju sistem peredaran darah, dan kemudian menyebar ke berbagai jaringan lain seperti ginjal, hati,otak, saraf dan tulang.

b. Styrofoam

Bahan pengemas styrofoam atau polystyrene telah menjadi salah satu pilihan yang paling populer dalam bisnis pangan. Tetapi, riset terkini membuktikan bahwa styrofoam diragukan keamanannya. Styrofoam yang dibuat dari kopolimer styren ini menjadi pilihan bisnis pangan karena mampu mencegah kebocoran dan tetap mempertahankan bentuknya saat dipegang. Selain itu, bahan tersebut juga mampu mempertahankan panas dan dingin tetapi tetap nyaman dipegang, mempertahankan kesegaran dan keutuhan bahan yang dikemas, biaya murah, lebih aman, serta ringan.

c. Kaleng

Umumnya, produk makanan yang dikemas dalam kaleng akan kehilangan citra rasa segarnya dan mengalami penurunan nilai gizi akibat pengolahan dengan suhu tinggi. Satu hal lagi yang juga cukup mengganggu adalah timbulnya rasa taint kaleng atau rasa seperti besi yang timbul akibat coating kaleng tidak sempurna. Bahaya utama pada makanan kaleng adalah tumbuhnya bakteri clostridium botulinum yang dapat menyebabkan keracunan botulinin. Tanda - tanda keracunan botulinin antara lain tenggorokan menjadi kaku, mata berkunang-kunang dan kejang-kejang yang membawa kematian karena sukar bernapas. Biasanya bakteri ini tumbuh pada makanan kaleng yang tidak sempurna pengolahannya atau

Copyright $\odot$ 2015, LITIGASI, p-ISSN: 0853-7100; e-ISSN: 2442-2274 
Available online at: http://ejournal.unpas.ac.id/index.php/litigasi

Litigasi, Vol. 16(1), 2015, 2610-2657

DOI: http://dx.doi.org/10.23969/litigasi.v16i1.50

pada kaleng yang bocor sehingga makanan di dalamnya terkontaminasi udara dari luar.

d. Plastik

Perlu diingat bahwa sebenarnya plastik itu tidak berbau dan berwarna. Jadi hindari penggunaan plastik yang bau dan berwarna gelap untuk membungkus makanan secara langsung. Plastik kresek hitam yang sering digunakan sebagai pembungkus gorengan, gelas plastik yang dipakai untuk air mendidih, botol kemasan air mineral yang diterpa sinar matahari setiap hari, serta penggunaan plastik kiloan untuk membuat ketupat, adalah contoh-contoh penggunaan kemasan plastik yang salah dan sangat berbahaya. Akibat dari penggunaan plastik yang tidak sesuai dengan fungsinya ini, dikhawatirkan akan terjadi perpindahan komponen kimia dari plastik ke dalam makanan.

Kantong plastik kresek yang selama ini sering digunakan masyarakat untuk mewadahi makanan terutama yang berwarna hitam kebanyakan merupakan produk daur ulang, demikian disampaikan Kepala Badan POM dr. Husniah Rubiana Thamrin Akib, MS, Mkes, SpFK dalam Peringatan Publik Badan POM di hadapan media massa pada tanggal 14 juli 2009. Lebih lanjut beliau mengatakan bahwa dalam proses daur ulang riwayat penggunaan sebelumnya tidak diketahui apakah bekas wadah pestisida, limbah rumah sakit, kotoran hewan atau manusia, limbah logam berat dan lain-lain. Dalam proses tersebut juga ditambahkan berbagai bahan kimia 
Available online at: http://ejournal.unpas.ac.id/index.php/litigasi

Litigasi, Vol. 16(1), 2015, 2610-2657

DOI: http://dx.doi.org/10.23969/litigasi.v16i1.50

yang menambah bahayanya bagi kesehatan. Karena itu jangan menggunakan kantong plastik daur ulang tersebut untuk mewadahi langsung makanan siap santap. Bertempat di ruang rapat pimpinan Badan POM, selain mengeluarkan peringatan publik mengenai kantong plastik "kresek", Kepala badan POM juga menyampaikan keterangan pers tentang Kemasan Makanan styrofoam atau Kemasan Makanan dari Plastik Poletilen (PE) dan Polipropilen (PE) serta satu peringatan publik lainnya yaitu tentang Kemasan Makanan dari Plastik Povinil Klorida (PVC). Terhadap kemasan plastik styrofoam, Badan POM telah melakukan sampling dan pengujian terhadap 17 jenis kemasan makanan styrofoam dan hasil pengujian menunjukkan semua kemasan tersebut memenuhi syarat. Pada umumnya, setiap kemasan makanan dapat dikenali dari logamnya. Stidaknya ada 8 kode jenis plastik yang lazim digunakan untuk kemasan makanan. (Warta POM, 2009).

Kepala Seksi Sertifikasi dan Layanan Konsumen Balai Besar Pengawasan Obat dan Makanan (BBPOM), Siti Nuraniah, menyatakan bahwa sebagian besar bahan kemasan pangan bersentuhan langsung (menempel) dengan pangan, jika menggunakan bahan yang mengandung racun, dikhawatirkan akan menempel pada produk pangan sehingga berbahaya bagi kesehatan masyarakat (http://www.pikiran-rakyat.com, 2009).

Copyright $\odot$ 2015, LITIGASI, p-ISSN: 0853-7100; e-ISSN: 2442-2274 
Available online at: http://ejournal.unpas.ac.id/index.php/litigasi

Litigasi, Vol. 16(1), 2015, 2610-2657

DOI: http://dx.doi.org/10.23969/litigasi.v16i1.50

Kemasan makanan merupakan bagian dari makanan yang sehari-hari di konsumsi oleh masyarakat. Bagi sebagian besar masyarakat, kemasan makanan hanya sekadar bungkus makanan dan cenderung dianggap sebagai "pelindung" makanan. Pandangan tersebut adalah keliru. Kemasan pada makanan mempunyai fungsi kesehatan, pengawetan, kemudahan, penyeragaman, promosi dan informasi. Ada begitu banyak bahan yang digunakan sebagai pengemas primer pada makanan, yaitu kemasan yang bersentuhan langsung dengan makanan. Tetapi tidak semua bahan ini aman bagi makanan yang dikemasnya. Hasil penelitian di lapangan menunjukan bahwa masyarakat pernah membeli produk makanan yang menggunakan kemasan. Produk makanan yang dibeli atau dikonsumsi tersebut beragam mulai dari makanan pokok sampai dengan makanan pelengkap. Produk makanan yang saya beli biasanya adalah susu, mie instan, kue kering, dan lain-lain. Produk makanan tersebut menggunakan kemasan yang terbuat dari bahan plastik, karton, kardus, alumunium foil. Kemasan tersebut berfungsi untuk melindungi makanan yang ada di dalamnya (Purnomo, 2012). Dari hasil penelitian dapat diketahui kemasan yang sering digunakan oleh masyarakat yang menjadi responden yaitu : kertas, styrofoam, kaleng, dan plastik.

Copyright $\odot$ 2015, LITIGASI, p-ISSN: 0853-7100; e-ISSN: 2442-2274 
Available online at: http://ejournal.unpas.ac.id/index.php/litigasi

Litigasi, Vol. 16(1), 2015, 2610-2657

DOI: http://dx.doi.org/10.23969/litigasi.v16i1.50

Tabel 1 : Penggunaan Bahan Kemasan

\begin{tabular}{|c|c|c|c|}
\hline No & Jenis Bahan Kemasan & Jumlah & Prosentase \\
\hline 1. & Kertas & 6 & $20 \%$ \\
\hline 2. & Plastik & 13 & $43 \%$ \\
\hline 3. & Styrofoam & 3 & $10 \%$ \\
\hline 4. & Kaleng & 3 & $10 \%$ \\
\hline 5. & Daun Pisang & 2 & $7 \%$ \\
\hline 6. & Alumunium Foil & 3 & $10 \%$ \\
\hline & Total Responden & 30 & $100 \%$ \\
\hline
\end{tabular}

Sumber : Hasil Penelitian yang telah diolah

Berdasarkan tabel di atas diketahui bahwa plastik merupakan penggunaan bahan kemasan yang sering digunakan oleh masyarakat, selain dari bahan kemasan lain yang juga digunakan. Masyarakat menggunakan bahan kemasan tersebut belum tentu mengetahui secara benar apakah kemasan tersebut baik atau tidak.

Tabel 2 : Pengetahuan Masyarakat Tentang Kemasan yang Baik Untuk Produk Makanan

\begin{tabular}{|c|c|c|c|}
\hline No & Tingkat Pengetahuan & Jumlah Responden & Prosentase \\
\hline 1. & Mengetahui & 3 & $10 \%$ \\
\hline 2. & Tidak Mengetahui & 27 & $90 \%$ \\
\hline & Total Responden & 30 & $100 \%$ \\
\hline
\end{tabular}

Sumber : Hasil Penelitian yang telah diolah

Berdasarkan tabel di atas diketahui bahwa pengetahuan masyarakat tentang kemasan yang baik untuk produk makanan masih rendah. Hasil penelitian menunjukan $90 \%$ tidak mengetahui kemasan yang baik untuk produk makanannya. Hal ini berbanding terbalik dengan apa yang 
Available online at: http://ejournal.unpas.ac.id/index.php/litigasi

Litigasi, Vol. 16(1), 2015, 2610-2657

DOI: http://dx.doi.org/10.23969/litigasi.v16i1.50

dikemukakan oleh Balai Besar POM Kota Semarang yang menyatakan bahwa instansi BBPOM telah melakukan sosialisasi kemasan yang baik untuk produk makanan (wawancara dengan Asih, staf BBPOM Kota Semarang, tanggal 12 Juni 2012).

Tabel 3 : Pemahaman Masyarakat Tentang Bahaya Kemasan yang tidak Baik Untuk Produk Makanan

\begin{tabular}{|c|c|c|c|}
\hline No & Tingkat Pengetahuan & Jumlah Responden & Prosentase \\
\hline 1. & Mengetahui & 9 & $30 \%$ \\
\hline 2. & Tidak Mengetahui & 21 & $70 \%$ \\
\hline & Total Responden & 30 & $100 \%$ \\
\hline
\end{tabular}

Sumber : Hasil Penelitian yang telah diolah

Berdasarkan tabel tersebut di atas dapat dianalisa bahwa masyarakat memiliki pemahaman yang kurang terhadap bahaya penggunaan kemasan yang tidak baik untuk produk makanan. Pemakaian yang tidak baik tersebut dapat pula dilakukan oleh masyarakat itu sendiri. Dengan kata lain penyalahgunaan kemasan yang tidak baik dilakukan oleh masyarakat sendiri, hal ini diakibatkan adanya pengetahuan yang kurang akan arti penting kemasan yang baik bagi produk makanan.

Copyright $\odot$ 2015, LITIGASI, p-ISSN: 0853-7100; e-ISSN: 2442-2274 
Available online at: http://ejournal.unpas.ac.id/index.php/litigasi

Litigasi, Vol. 16(1), 2015, 2610-2657

DOI: http://dx.doi.org/10.23969/litigasi.v16i1.50

Tabel 4 : Pengetahuan Masyarakat Tentang Regulasi Tentang Kemasan Produk Makanan

\begin{tabular}{|c|c|c|c|}
\hline No & Tingkat Pengetahuan & Jumlah Responden & Prosentase \\
\hline 1. & Mengetahui & 5 & $17 \%$ \\
\hline 2. & Tidak Mengetahui & 25 & $83 \%$ \\
\hline & Total Responden & 30 & $100 \%$ \\
\hline
\end{tabular}

Sumber : Hasil Penelitian yang telah diolah

Pengamatan terhadap konsumen yang membeli bakmi dengan dibungkus dalam kemasan styrofoam, mereka mengatakan dengan dibungkus dalam bentuk kotak, begitu praktis, makanan bisa tahan lama panasnya. Namun mereka tidak menyadari dampak dari kemasan styrofoam bisa menyebabkan kanker, gagal ginjal dan mempengaruhi kesehatan lainnya.

Kehidupan masyarakat saat ini semakin komplek, hasil produk begitu melimpah, faktor keselamatan bagi para konsumen dalam menikmati hasil produk perlu diperhatikan seperti produk makan dan minuman. Demi keselamatan dan keamanan bagi konsumen para produsen dituntut untuk betul-betul memperhatikan mutu kemasan yang dapat memberi perlindungan juga sebagai bagian dari tanggung jawab produsen. Sebenarnya berbagai jenis dan bentuk kemasan memudahkan makanan dan minuman didistribusikan karena lebih awet, higienis jika dikemas dengan baik. Konsumen merasa nyaman dengan tersedianya produk pangan terkemas berbagai bentuk dan ukuran, disatu sisi kemasan memberikan keuntungan dan disisi lain 
Available online at: http://ejournal.unpas.ac.id/index.php/litigasi

Litigasi, Vol. 16(1), 2015, 2610-2657

DOI: http://dx.doi.org/10.23969/litigasi.v16i1.50

kemasan juga perlu diwaspadai karena tidak semua bahan pengemas aman terhadap makanan dan minuman sehingga harus memenuhi syarat kemasan. Oleh karena itu Undang-Undang No 7 tahun 1996 tentang Pangan pada bagian keempat memberikan pengaturan mengenai kemasan pangan yang harus diperhatikan bagi semua produsen dalam memproduksi makanan dan minuman sebagai bentuk tanggung jawabnya.

2. Penegakan Hukum Terhadap Pelanggaran Penyalahgunaan Pemakaian Kemasan Pada Produk Makanan

Globalisasi dan perdagangan bebas yang didukung oleh kemajuan teknologi telekomunikasi dan informatika telah memperluas ruang gerak arus transaksi barang dan/atau jasa melintasi batas-batas wilayah suatu negara, sehingga barang dan/atau jasa yang ditawarkan bervariasi atau bermacammacam. Barang-barang tersebut tidak lain baik yang diproduksi dari dalam negeri maupun produksi luar negeri. Kondisi yang demikian pada satu pihak mempunyai manfaat bagi konsumen karena kebutuhan konsumen akan barang dan/atau jasa yang diinginkan dapat terpenuhi serta semakin terbuka lebar kebebasan untuk masyarakat memilih aneka jenis dan kualitas barang dan/atau jasa sesuai dengan keinginan dan kemampuan konsumen.

Kondisi yang telah dipaparkan di atas dapat mengakibatkan kedudukan pelaku usaha dan konsumen menjadi tidak seimbang dan konsumen berada pada posisi yang lemah. Konsumen menjadi objek aktivitas bisnis untuk

Copyright @ C 2015, LITIGASI, p-ISSN: 0853-7100; e-ISSN: 2442-2274 
Available online at: http://ejournal.unpas.ac.id/index.php/litigasi

Litigasi, Vol. 16(1), 2015, 2610-2657

DOI: http://dx.doi.org/10.23969/litigasi.v16i1.50

meraup keuntungan yang sebesar-besarnya oleh pelaku usaha melalui kiat promosi, cara penjualan, serta penerapan perjanjian standar yang merugikan konsumen.

Faktor utama yang menjadi kelemahan konsumen adalah tingkat kesadaran konsumen akan haknya masih rendah. Hal ini terutama disebabkan oleh rendahnya pendidikan konsumen. Jadi hukum berkembang dari kesadaran masyarakat bahwa hukum dibutuhkanya demi suatu kehidupan yang dinilai baik dan bermutu. Jadi dasar adanya hukum adalah penilaian masyarakat bahwa hukum itu diperlukan (Franz Magnis, 1991). Oleh karena itu, Undang-Undang Perlindungan Konsumen dimaksudkan menjadi landasan hukum yang kuat bagi pemerintah dan lembaga perlindungan konsumen swadaya masyarakat untuk melakukan upaya pemberdayaan konsumen melalui pembinaan dan pendidikan konsumen $(C, S, T$, Kansil dan Christine S,T, Kansil, 2008).

Salah satu sentral pokok dalam memberikan perlindungan kepada konsumen adalah peraturan yang mengatur tentang produk makanan, khususnya dalam proses pembuatannya maupun dalam proses pemasaran produknya. Dalam melakukan pemasaran suatu produk, kemasan memegang peranan yang penting, dimana kemasan sebagai wadah produk dan daya tarik produk. Tetapi dalam kenyataannya tidak semua produsen dalam membuat kemasan untuk produknya mematuhi segala peraturan yang ada.

Copyright @ 2015 , LITIGASI, p-ISSN: 0853-7100; e-ISSN: 2442-2274 
Available online at: http://ejournal.unpas.ac.id/index.php/litigasi

Litigasi, Vol. 16(1), 2015, 2610-2657

DOI: http://dx.doi.org/10.23969/litigasi.v16i1.50

Hukum berfungsi sebagai perlindungan kepentingan manusia. Agar kepentingan manusia terlindungi, hukum harus dilaksanakan. Pelaksanaan hukum dapat berlangsung secara normal, damai, tetapi juga dapat terjadi karena pelanggaran hukum. Dalam hal ini hukum yang telah dilanggar harus ditegakkan. Dalam menegakkan hukum ada 3 (tiga) unsur yang harus diperhatikan, yaitu kepastian hukum (Rechtssicherheit), kemanfaatan hukum (Zweekmassigkeit) dan keadilan/Gerechtigkeit (Sudikno Mertokusumo, 2003).

Unsur-unsur yang terdapat dalam penegakkan hukum harus dilaksanakan oleh aparatur negara yang mendapat tugas sebagai penegak hukum. Dalam menegakkan hukum, setiap aparatur penegak hukum mempunyai tatanan atau aturan main yang berbeda-beda sesuai dengan tugas, fungsi dan wewenang yang diembannya. Syarat-syarat agar fungsi hukum dapat terlaksana dengan baik, maka para penegak hukum dituntut kemampuannya untuk melaksanakan dan menerapkan hukum dengan baik, dengan seni yang dimiliki masing-masing petugas, misalnya : menafsirkan hukum sesuai dengan keadilan dan posisi masing-masing, bila perlu diadakan penafsiran analogis penghalusan hukum atau memberi ungkapan a contrario, disamping hal-hal tersebut diatas dibutuhkan kecakapan dan keterampilan serta ketangkasan para penegak hukum dalam menerapkan hukum yang berlaku. Pulihnya ketentraman dan ketertiban umum dapat meningkatkan kredibilitas dan kewibawaan aparatur penegak hukum.

Copyright @ 2015 , LITIGASI, p-ISSN: 0853-7100; e-ISSN: 2442-2274 
Available online at: http://ejournal.unpas.ac.id/index.php/litigasi

Litigasi, Vol. 16(1), 2015, 2610-2657

DOI: http://dx.doi.org/10.23969/litigasi.v16i1.50

Penegakkan (menegakkan) hukum (law enforcement), atau disebut juga mempertahankan hukum (handhaving van het recht), setidak-tidaknyamemuat dua makna. Pertama; menjaga atau memelihara agar hukum tetap dipatuhi atau dijalankan. Kedua; mencegah dan mengambil tindakan terhadap penyimpangan atau pelanggaran hukum. Tujuan menghalalkan segala cara: the end justifies the means (Bagir Manan, 2010).

Menurut Black's Law Dictionary, penegakan hukum (law enforcement), diartikan sebagai "The act of putting something such as a law into effect; the execution of a law; the carriying out of $s$ mandate or command. Secara sederhana dapat dikatakan bahwa penegakkan hukum merupakan usaha untuk menegakkan norma-norma dan kaidah-kaidah hukum sekaligus nilai-nilai yang ada di belakangnya. Dengan demikian aparat penegak hukum hendaknya memahami benar-benar jiwa hukum (legal spirit) yang mendasari peraturan hukum yang harus ditegakkan, terkait dengan berbagai dinamika yang terjadi dalam proses pembuatan perundang-undangan/law making process (Muladi, 2002).

Regulasi yang telah melandasi kemasan makanan yang telah dijelaskan di atas merupakan dasar hukum yang memayungi perihal kemasan makanan. Regulasi yang ada tersebut dalam masyarakat yang dikenal sebagai suatu bentuk hukum diimplementasikan sedemikian rupa agar menjadi patokan dalam bertindak dalam masyarakat. Regulasi tentang kemasan makanan dan minuman di Indonesia bermacam-macam, mulai dari Undang-Undang No.

Copyright $\odot$ 2015, LITIGASI, p-ISSN: 0853-7100; e-ISSN: 2442-2274 
Available online at: http://ejournal.unpas.ac.id/index.php/litigasi

Litigasi, Vol. 16(1), 2015, 2610-2657

DOI: http://dx.doi.org/10.23969/litigasi.v16i1.50

36 Tahun 2009 Tentang Kesehatan, Undang-Undang No. 8 Tahun 1999 Tentang Perlindungan Konsumen, PP No. 28 Tahun 2004 Tentang Keamanan, Mutu, dan Gizi Pangan, Keputusan BPOM tentang bahan Kemasan Pangan, dan lain sebagainya. Setiap regulasi mengatur bagaimana seharusnya ketentuan kemasan makanan yang memenuhi syarat dan tidak berakibat buruk bagi kesehatan. Penggunaan kemasan makanan juga diawasi secara langsung oleh pemerintah.

Implementasi dari regulasi tentang kemasan makanan dan minuman di Indonesia bahwa hukum atau regulasi yang ada belum cukup memberikan kesadaran dan pemahaman akan arti pentingnya ketentuan penggunaan kemasan makanan dan minuman pada masyarakat. Regulasi yang ada perlu ditindak lanjuti dengan sosialisasi secara berkala kepada masyarakat luas dan didukung oleh masyarakat itu sendiri.

Regulasi tersebut tidak akan ada artinya manakala tidak diimbangi dengan penegakan hukum terhadap pelanggaran dari penyalahgunaan kemasan makanan yang dilakukan baik oleh produsen ataupun pihak-pihak lain dengan sengaja. Masyarakat tidak hanya membutuhkan berbagai macam regulasi mengenai kemasan tanpa ada suatu upaya konkret dari pemerintah untuk menindaklanjuti atau merealisasikan apa yang ada dalam regulasi tersebut.

Copyright @ 2015, LITIGASI, p-ISSN: 0853-7100; e-ISSN: 2442-2274 
Available online at: http://ejournal.unpas.ac.id/index.php/litigasi

Litigasi, Vol. 16(1), 2015, 2610-2657

DOI: http://dx.doi.org/10.23969/litigasi.v16i1.50

Soerjono Soekanto menekankan pada masalah pokok dalam penegakkan hukum sebenarnya terletak pada faktor-faktor yang mungkin mempengaruhinya. Faktor-faktor tersebut adalah: (1) Faktor hukum; (2) Faktor penegak hukum, yakni pihak-pihak yang membentuk maupun menerapkan hukum; (3) Faktor sarana atau fasilitas yang mendukung penegakkan hukum; (4) Faktor masyarakat, yakni lingkungan di mana hukum tersebut berlaku atau diterapkan; (5) Faktor kebudayaan, yakni sebagai hasil karya, cipta dan rasa yang didasarkan pada karsa manusia di dalam pergaulan hidup (Soerjono Soekanto, 2010). Pada penegakkan hukum kasus pelanggaran kemasan yang tidak baik pada makanan lebih menekankan pada faktor masyarakat yang memiliki kesadaran rendah akan arti penting hukum bagi masyarakat dan rendahnya pemahaman akan hak dan kewajiban dalam hukum.

Penggunaan kemasan pangan yang diproduksi dari bahan plastik daur ulang tanpa pemeriksaan pendahuluan di laboratorium dilarang digunakan, karena dikhwatirkan terjadi migrasi zat kimia beracun yang menempel pada produk pangan melebihi ambang batas (http://www.pikiran-rakyat.com, 2009). Dari hasil penelitian diketahui bahwa masyarakat tidak melakukan pengaduan terhadap podusen atau pihak yang menggunakan kemasan yang tidak baik. Hal ini dikarenakan akibat dari kemasan yang tidak baik bagi kesehatan dapat diketahui dalam jangka waktu yang relatif lama. Sehingga tidak bisa diketahui dengan pasti produk makanan mana yang telah membuat

Copyright $\odot$ 2015, LITIGASI, p-ISSN: 0853-7100; e-ISSN: 2442-2274 
Available online at: http://ejournal.unpas.ac.id/index.php/litigasi

Litigasi, Vol. 16(1), 2015, 2610-2657

DOI: http://dx.doi.org/10.23969/litigasi.v16i1.50

mereka menjadi sakit. Komplain atau pengaduan hanya sekedar ketidakpuasan masyarakat terhadap pelayanan produsen kepada konsumen saja. Pandangan yang demikian merupakan pandangan yang keliru karena masyarakat memiliki hak untuk melakukan pengaduan atau komplain kepada pihak-pihak terkait berkaitan dengan penggunaan kemasan yang tidak baik bagi produk makanan. Pelaporan atau pengaduan kepada pihak aparat penegak hukum terlalu rumit prosedur maupun penyelesaiannya (Syahril Fadlil, 2012). Kemasan yang dipandang memenuhi syarat keamanan dan keselamatan konsumen adalah kemasan baik langsung maupun tidak langsung tidak mencemari makanan yang dikemasnya dan dalam kesehatan dapat dipertanggungjawabkan. Bila ketentuan mengenai kemasan dilanggar oleh produsen, maka dapat dikenakan sanksi : 1). Secara keperdataan dapat digugat ganti rugi oleh konsumen yang merasa dirugikan, 2). Secara kepidanaan dapat dijatuhi hukuman penjara atau denda, 3). Secara administrasi dapat dikenakan sanksi administrasi : peringatan secara tertulis dan atau pencabutan ijin produksi.

Penegakkan hukum merupakan sub sistem sosial, sehingga penegakannya dipengaruhi lingkungan yang sangat kompleks seperti perkembangan politik, ekonomi, sosial, budaya, hankam, iptek, pendidikan dan sebagainya. Penegakkan hukum harus berlandaskan kepada prinsipprinsip negara hukum sebagaimana tersurat dan tersirat dalam UUD 1945 dan asas-asas hukum yang berlaku di lingkungan bangsa-bangsa yang beradab

Copyright @ $\odot$ 2015, LITIGASI, p-ISSN: 0853-7100; e-ISSN: 2442-2274 
Available online at: http://ejournal.unpas.ac.id/index.php/litigasi

Litigasi, Vol. 16(1), 2015, 2610-2657

DOI: http://dx.doi.org/10.23969/litigasi.v16i1.50

seperti The Basic Principles of Independence of Judiciary, 1985, agar penegak hukum dapat menghindarkan diri dari praktik-praktik negatif akibat pengaruh lingkungan yang sangat kompleks tersebut (Muladi, 2002).

Hukum dalam fungsinya sebagai perlindungan kepentingan manusia, mempunyai tujuan. Tujuan pokok hukum adalah menciptakan tatanan masyarakat yang tertib, menciptakan ketertiban dan keseimbangan. Dalam mencapai tujuannya itu, hukum bertugas membagi hak dan kewajiban antara perseorangan di dalam masyarakat, membagi wewenang dan mengatur cara memecahkan masalah hukum serta memelihara kepastian hukum (Sudikno Mertokusumo, 2003). Suatu ketertiban akan dapat dicapai dengan kepastian hukum, sedangkan ketentraman akan tercapai dengan kesebandingan hukum. Ketertiban merupakan suatu kebutuhan umum, yang secara psikologis adalah suatu "principle of necessity". Ketentraman merupakan suatu kebutuhan pribadi, yang secara psikologis haruslah senatiasa juga dipenuhi, dan lazimnya dinamakan sebagai "principle of pleasure". Keduanya itu harus selalu diserasikan di dalam sistem kesehatan (nasional) agar supaya sistem tersebut mencapai tujuannya di dalam menciptakan kesejahteraan yang maksimal bagi umat manusia dalam kehidupan bermasyarakat dan bernegara (Soerjono Soekanto, 1989).

Copyright $\odot$ 2015, LITIGASI, p-ISSN: 0853-7100; e-ISSN: 2442-2274 
Available online at: http://ejournal.unpas.ac.id/index.php/litigasi

Litigasi, Vol. 16(1), 2015, 2610-2657

DOI: http://dx.doi.org/10.23969/litigasi.v16i1.50

Tabel 5 : Pengaduan Masyarakat Tentang Kemasan yang tidak Baik Untuk Produk Makanan

\begin{tabular}{|c|c|c|c|}
\hline No & Tingkat Pengetahuan & Jumlah Responden & Prosentase \\
\hline 1. & Mengadukan & 1 & $3 \%$ \\
\hline 2. & Tidak Mengadukan & 30 & $97 \%$ \\
\hline & Total Responden & 30 & $100 \%$ \\
\hline
\end{tabular}

Sumber : Hasil Penelitian yang telah diolah

Berdasarkan tabel tersebut di atas dapat diketahui bahwa masyarakat memiliki tingkat pengaduan yang rendah terhadap penyalahgunaan kemasan produk makanan.

Kami tidak mengadukan kepada aparat penegak hukum bila ada penyalahgunaan pemakaian kemasan makanan karena kami tidak merasakan kerugian tersebut secara langsung (Patricia Masrinda, 2010). Pengaduan atau kritik terhadap penyalahgunaan penggunaan kemasan yang tidak baik dilakukan dengan tidak membeli produk tersebut lagi (Dwi Erna, 2010).

Orang dapat menganggap lain atas istilah penegakkan hukum itu dan memberi tekanan pada faktor-faktor yang telah menentukan isi sesungguhnya dari hukum. Namun untuk mencapai supremasi hukum yang kita harapkan bukan faktor hukumnya saja, namun faktor aparat penegak hukum juga sangat berpengaruh dalam mewujudkan supremasi hukum walaupun tidak itu saja. Orang mulai tidak percaya terhadap hukum dan proses hukum ketika hukum itu sendiri masih belum dapat memberikan keadilan dan perlindungan bagi masyarakat.

Copyright @ 2015 , LITIGASI, p-ISSN: 0853-7100; e-ISSN: 2442-2274 
Available online at: http://ejournal.unpas.ac.id/index.php/litigasi

Litigasi, Vol. 16(1), 2015, 2610-2657

DOI: http://dx.doi.org/10.23969/litigasi.v16i1.50

Ketentuan mengenai kemasan makanan dan minuman memiliki sanksi yang dapat diterapkan apabila ketentuan yang ada dalam regulasi dilanggar. Sanksi yang ada berupa sanksi secara keperdataan dan secara pidana. Sanksi perdata yaitu dapat digugat ganti rugi oleh konsumen yang merasa dirugikan. Dan secara kepidanaan dapat dijatuhi hukuman penjara atau denda. Selain itu ada sanksi yang bersifat administrasi. Secara administrasi dapat dikenakan sanksi administrasi : peringatan secara tertulis dan atau pencabutan ijin produksi.

Beberapa sanksi yang diterapkan terhadap penggunaan kemasan makanan yang tidak baik dan merugikan kesehatan orang lain yaitu :

a. KUHP (Pasal 204 dan Pasal 386)

Kitab Undang Undang Hukum Pidana secara tegas menyatakan sanksi dalam Pasal 204 dan Pasal 386. Sanksi yang diterapkan dalam KUHP merupakan ancaman pidana. Pasal 204 KUHP menyebutkan bahwa siapapun yang menjual, menawarkan, menyerahkan atau membagi-bagikan barang, yang diketahui bahwa membahayakan nyawa atau kesehatan orang, padahal sifat berbahayanya itu tidak diberitahukan, diancam dengan pidana penjara paling lama lima belas tahun. Tetapi jika perbuatan tersebut menyebabkan matinya orang, yang bersalah dikenakan pidana penjara seumur hidup atau pidana penjara selama waktu tertentu paling lama dua puluh tahun. Sedangkan dalam Pasal 386 KUHP menyebutkan bahwa : siapapun yang menjual, menawarkan, atau menyerahkan barang, makanan,

Copyright $\odot$ 2015, LITIGASI, p-ISSN: 0853-7100; e-ISSN: 2442-2274 
Available online at: http://ejournal.unpas.ac.id/index.php/litigasi

Litigasi, Vol. 16(1), 2015, 2610-2657

DOI: http://dx.doi.org/10.23969/litigasi.v16i1.50

minuman atau obat-obatan yang diketahui bahwa itu palsu, dan menyembunyikan hal itu, diancam dengan pidana penjara paling lama empat tahun.

b. Undang-Undang Nomor 23 Tahun 1992 Tentang Kesehatan Undang-Undang Kesehatan tak luput memberikan sanksi terkait dalam masalah kemasan makanan yaitu Pasal 80 ayat (4) dimana siapapun dengan sengaja mengedarkan makanan dan atau minuman yang tidak memenuhi standar dan atau persyaratan dan atau membahayakan kesehatan dipidana dengan pidana penjara paling lama 15 (lima belas) tahun atau pidana denda paling banyak Rp 300.000.000,00 (tiga ratus juta rupiah). Pasal 84 ayat (1) siapapun yang mengedarkan makanan dan/atau minuman yang dikemas tanpa mencantumkan tanda atau label dipidana dengan pidana kurungan paling lama 1 (satu) tahun dan atau pidana denda paling banyak Rp 15.000.000,00 (lima belas juta rupiah).

\section{c. Undang-Undang Nomor 7 Tahun 1996 Tentang Pangan}

Para produsen makanan bila ternyata telah melakukan pelanggaran mengenai bahan kemasan makanan menurut UU No. 7 tahun 1996 tentang pangan dapat dikenakan sanksi. Siapapun dengan sengaja menggunakan bahan yang dilarang digunakan sebagai kemasan pangan dan atau bahan apapun yang dapat melepaskan cemaran yang merugikan atau membahayakan kesehatan manusia dipidana dengan pidana penjara paling

Copyright $\odot$ 2015, LITIGASI, p-ISSN: 0853-7100; e-ISSN: 2442-2274 
Available online at: http://ejournal.unpas.ac.id/index.php/litigasi

Litigasi, Vol. 16(1), 2015, 2610-2657

DOI: http://dx.doi.org/10.23969/litigasi.v16i1.50

lama 5 ( lima ) tahun dan atau denda paling banyak Rp. 600.000.000 (enam ratus juta rupiah). Sanksi lain yaitu siapapun karena kelalaiannya menggunakan bahan yang dilarang digunakan sebagai kemasan pangan dan atau bahan apapun yang dapat melepaskan cemaran yang merugikan atau membahayakan kesehatan dipidana dengan pidana penjara paling lama 1 tahun dan atau denda paling banyak seratus dua puluh juta rupiah. Siapapun yang menggunakan suatu bahan sebagai kemasan pangan untuk diedarkan secara bertentangan atau membuka kemasan akhir pangan untuk dikemas kembali dan memperdagangkannya dipidana dengan pidana penjara paling lama 3 tahaun dan atau denda paling banyak tiga ratus enam puluh juta rupiah. Siapapun yang tidak melaksanakan tata cara pengemasan pangan meskipun telah diperingatkan secara tertulis oleh pemerintah, dipidana dengan pidana penjara paling lama empat tahun dan atau denda paling banyak empat ratus delapan puluh juta rupiah.

Copyright $\odot$ 2015, LITIGASI, p-ISSN: 0853-7100; e-ISSN: 2442-2274 
Available online at: http://ejournal.unpas.ac.id/index.php/litigasi

Litigasi, Vol. 16(1), 2015, 2610-2657

DOI: http://dx.doi.org/10.23969/litigasi.v16i1.50

\section{SIMPULAN DAN SARAN}

\section{A. Simpulan}

1. Tingkat pemahaman masyarakat Kota Semarang terhadap bahaya penyalahgunaan pemakaian kemasan produk makanan masih rendah. Masyarakat belum memahami secara utuh regulasi yang telah dikeluarkan pemerintah mengenai kemasan makanan, karena masih saja ada masyarakat yang melakukan penggunaan kemasan makanan secara tidak baik. Hal ini dapat disebabkan karena kurangnya pengetahuan masyarakat akan arti pentingnya penggunaan kemasan makanan atau kurangnya sosialisasi pemerintah kepada masyarakat mengenai regulasi yang ada atau masyarakat sendiri yang kurang peduli akan pentingnya penggunaan kemasan makanan yang baik.

2. Regulasi yang dikeluarkan oleh pemerintah untuk menjamin adanya keselamatan bagi masyarakat dalam kemasan makanan yaitu mengacu pada Undang-Undang No. 7 Tahun 1996 tentang Pangan, dan berbagai peraturan perundang-undangan yang berlaku lainnya seperti Undang-Undang No. 36 Tahun 2009 Tentang Kesehatan, UU No. 8 Tahun 1999 Tentang Perlindungan Konsumen, PP No. 28 Tahun 2004 Tentang Keamanan, Mutu, dan Gizi Pangan, Keputusan BPOM Tentang bahan Kemasan Pangan, dan lain sebagainya. Regulasi tersebut tidak akan ada artinya manakala tidak diimbangi dengan 
Available online at: http://ejournal.unpas.ac.id/index.php/litigasi

Litigasi, Vol. 16(1), 2015, 2610-2657

DOI: http://dx.doi.org/10.23969/litigasi.v16i1.50

penegakkan hukum terhadap pelanggaran dari penyalahgunaan kemasan makanan yang dilakukan baik oleh produsen ataupun pihakpihak lain dengan sengaja. Masyarakat tidak hanya membutuhkan berbagai macam regulasi mengenai kemasan tanpa ada suatu upaya konkret dari pemerintah untuk menindaklanjuti atau merealisasikan apa yang ada dalam regulasi tersebut. Penegakkan hukum menjadi suatu pertanyaan besar dalam hal pengemasan makanan. Ada peraturan tetapi jangan bertanya mengenai penegakkannya. Dari hasil penelitian tidak ada masyarakat yang mengadukan kepada pihak penegak hukum mengenai kemasan makanan yang berbahaya bagi dirinya. Hal ini dapat dipahami karena kesadaran masyarakat kurang. Selain itu bahaya penyalahgunaan kemasan makanan tidak seketika tetapi memiliki jangka waktu yang relatif lama. Tolak ukur dari efektivitas penegakkan hukum tidak hanya dari faktor hukumnya itu sendiri (undang-undang), namun ada banyak faktor lain termasuk diantaranya adalah faktor masyarakat. Masyarakat dapat mempengaruhi penegakkan hukum dengan pemahaman masyarakat mengenai hukum itu sendiri yang pada akhir akan mempengaruhi kepatuhan hukum pada masyarakat. Masyarakat yang sadar akan pentingnya kesehatan dan hukum memberikan jaminan dalam regulasinya perihal penggunaan kemasan yang baik, maka dengan partisipasi masyarakat dapat terwujud penegakkan hukum yang baik.

Copyright @ $\odot$ 2015, LITIGASI, p-ISSN: 0853-7100; e-ISSN: 2442-2274 
Available online at: http://ejournal.unpas.ac.id/index.php/litigasi

Litigasi, Vol. 16(1), 2015, 2610-2657

DOI: http://dx.doi.org/10.23969/litigasi.v16i1.50

B. Saran

1. Informasi mengenai bahaya penggunaan kemasan makanan ini tidak hanya untuk dibaca tetapi juga untuk dipahami dan dilaksanakan agar masyarakat dapat mencegah penggunaan kemasan makana yang berbahaya atau tidak tepat dan berlebihan karena dapat merusak kesehatan dan lingkungan;

2. Meningkatkan pemahaman masyarakat terhadap bahaya penyalahgunaan pemakaian kemasan untuk makanan agar dapat menghindari akibat buruk dari penyalahgunaan tersebut;

3. Para produsen makanan dan minuman untuk benar-benar mentaati peraturan perundang-undangan yang berhubungan dengan kemasan, pembungkus atau wadah agar keamanan konsumen dapat terjamin;

4. Pemerintah bertindak tegas dalam memberikan sanksi atas penyimpangan dalam kemasan makanan oleh produsen;

5. Pemerintah melalui BPOM untuk meningkatkan pengawasannya terhadap kemasan hasil produk makanan;

6. Perlu ditingkatkan kerja sama dalam pengawasan antara BPOM Departemen Kesehatan dengan lembaga swadaya masyarakat (LSM) dan juga lembaga konsumen;

7. Hindari penggunaan kemasan plastik untuk produk yang masih panas karena plastik sangat rentan dengan suhu tinggi;

8. Melakukan sosialisasi kepada masyarakat untuk Back to Nature, dalam arti kembali menggunakan kemasan tradisional yang sudah teruji keamanannya. Memberikan pemahaman kepada masyarakat sebelum menggunakan kemasan

Copyright @ C 2015, LITIGASI, p-ISSN: 0853-7100; e-ISSN: 2442-2274 
Available online at: http://ejournal.unpas.ac.id/index.php/litigasi

Litigasi, Vol. 16(1), 2015, 2610-2657

DOI: http://dx.doi.org/10.23969/litigasi.v16i1.50

plastik, perhatikan kode kemasan plastik yang terletak di bawah kemasan berbentuk segitiga, agar kita mengetahui apakah jenis plastik ini sesuai yang disarankan. Memberikan pengetahuan dan wawasan kepada masyarakat untuk memisahkan antara sampah organik dan sampah anorganik. Sampah plastik tidak mudah untuk terurai, maka mendaur ulang sampah plastik secara mandiri sangat disarankan.

Copyright @ 2015, LITIGASI, p-ISSN: 0853-7100; e-ISSN: 2442-2274 


\section{DAFTAR PUSTAKA}

\section{BUKU}

Ahmad Yani \& Gunawan Widjaja. 2002. Seri Hukum Bisnis (Anti Monopoli). Jakarta : PT. RajaGrafindo Persada.

C.S. T, Kansil dan Christine S.T, Kansil. 2008. Pokok-pokok Pengetahuan Hukum Dagang Indonesia. Jakarta : Sinar Grafika.

David, Silverman. 1993. Interpretating Qualitative Data. New Delihi : Sage Publications.

Esmi Warrassih. 1999. Metodologi Penelitian Bidang Ilmu Humaniora. (Bahan Pelatihan Metodologi Penelitian Bagian Hukum dan Masyarakat), Semarang : Fak. Hukum Undip.

FG, Winarno. 2001. Residu "Styrofoam" Semakin Berbahaya bagi Kesehatan. Jakarta : Koran Kompas.

Franz Magnis Suseno. 1991. Etika Politik . Jakarta : PT Gramedia.

Hendrojono. 2005. Sosiologi Hukum (Pengaruh Perubahan Masyarakat dan Hukum). Surabaya : PT. Dieta Persada.

Miles, Matthew dan Huberman. 1992. Analisis Data Kualitatif. Jakarta : UI Press.

Mikkelsen, Britha. Alih bahasa Matheos Nalle. 1999. Metode Penelitian Partisipatoris dan Upaya-Upaya Pemberdayaan, Sebuah Bukum Pegangan bagi Para Praktisi Lapangan. Jakarta : Yayasan Obor Indonesia.

M.L, Tobing. 1983. Sekitar Pengantar IImu Hukum. Jakarta : Erlangga.

Muladi. 2002. Hak Asasi Manusia, Politik dan Sistem Peradilan Pidana. Semarang : Badan Penerbit Universitas Diponegoro.

Mukti Fajar dan Yulinto Ahmad. 2010. Dualisme Penelitian Hukum Normatif \& Empiris. Yogyakarta : Pustaka Pelajar.

Moleong, J. Lexy. 1996. Metode Penelitian Kualitatif. Bandung : Remaja Rosdakarya.

R, Soeroso. 2004. Pengantar Ilnu Hukum. Jakarta : Sinar Grafika. 
Ronny Hanitijo Soemitro. 1990. Metode Penelitian Hukum dan Jurimetri. Jakarta : Ghalis Indonesia.

Satjipto Rahardjo. 2004. Sosiologi Hukum : Perkembangan Metode dan Pilihan Masalah. Surakarta : Penerbit Muhammadiyah University Press.

. 1997. Pemanfaatan ilmu -ilmu sosial Bagi Pengembangan ilmu hukum. Alumni : Bandung.

. 2010. Penegakan Hukum Progresif. Jakarta : Kompas.

Genta Publishing.

.2009. Penegakan Hukum Suatu Tinjauan Sosiologis. Yogyakarta : . 2009. Sisi-sisi Lain dari Hukum di Indonesia. Jakarta : Kompas.

Syarif $R$, dan S, Isyana. 1989. Teknologi Pengemasan pangan. Laboratorium Rekayasa Proses Pangan, PAU-Pangan dan Gizi. Bogor : Institut Pertanian Bogor.

Sudikno Mertokusumo. 2003. Mengenal Hukum (Suatu Pengantar). Yogyakarta : Penerbit Liberty.

Soerjono Soekanto. 1984. Pengantar Penelitian Hukum. Jakarta : UI Press.

. 1989. Aspek Hukum Kesehatan (Suatu Kumpulan Catatan). Jakarta : IND-HILL-CO.

. 2007. Faktor-faktor yang Mempengaruhi Penegakan Hukum. Jakarta : Pt. Raja Grafindo Persada.

Soerjono Soekanto dan Sri Mamudji. 2004. Penelitian Hukum Normatif : Suatu Tinjauan Singkat. Cetakan Kedelapan. Jakarta : PT. Raja Grafindo Persada.

Warta POM. Volume 7 Edisi Juli - Agustus 2009. Jakarta : Badan POM RI. 
Available online at: http://ejournal.unpas.ac.id/index.php/litigasi

Litigasi, Vol. 16(1), 2015, 2610-2657

DOI: http://dx.doi.org/10.23969/litigasi.v16i1.50

\section{MAJALAH}

Bagir Manan. 2010. Penegakan Hukum dalam Perkara Pidana. Varia Peradilan.

\section{WEBSITE}

Anies. 2009. Bahaya "Kresek" dan Kemasan Styrofoam. http://suaramerdeka.com/v1/index.php/read/cetak/2009/07/23/73483/B ahaya-Kresek-dan-Kemasan-Styrofoam. diakses tanggal [20 Maret 2010].

http://www.indonesianegeriku.com/Artikel/supaya-tetap-sehat.html, diakses tanggal 14 Juli 2009.

http://www.organisasi.org,Waspada Kemasan Pembungkus Makanan dan Minuman Beracun Mengandung Zat Berbahaya Bagi Kesehatan, diakses tanggal 9 juli 2009.

http://www.suarakarya-online.com/news.html?id=205955, diakses tanggal 10 Juli 2009.

http://www.pikiran-rakyat.com, diakses tanggal 14 Juli 2009. 